\title{
Islamization vs. Islamophobia: A New Historicist Reading of Cold War Politics in Contemporary Pakistani Anglophone Fiction
}

https://doi.org/10.33806/ijaes2000.22.1.14

\author{
Malik Haroon Afzal, Mohamad Rashidi Mohd Pakri, and Nurul Farhana \\ Low Abdullah \\ University Sains Malaysia, Malaysia
}

Received on 17.3.2021

Accepted on 12.10.2021

Published on 1.1.2022

\begin{abstract}
Islamization and Islamophobia present two different narratives. Since Cold War, these two narratives have been influencing Muslims globally, especially Pakistan due to its support of Talibanization during the Soviet (communist) invasion of Afghanistan. Pakistan's initial support of Talibanization in coalition with America, where the country yielded a religiously extremist status, provides a premise to suspect America and the West's (capitalists) role in its development. The treatment of the very 'Muslim identity in the preCold War and the post-Cold War contexts reveals an interesting shift in the Western approach towards Muslims. The pre-Cold War era shows overt Western support for the narrative of Islamization in Muslim countries, whereas the post-Cold War era shows a sudden bounce of anti-Muslim sentiments in the West. This shift calls into question the role of power in the development of both narratives. Using Stephen Greenblatt's critique of selffashioning, subversion, containment, and power, we aim to explore both narratives concerning the selected Pakistani Anglophone fiction: Muhammad Hanif's A Case of Exploding Mangoes (2008) and Hanif Kureishi's The Black Album (1995). The current article concludes that Islamization and Islamophobia are both political policies that have been serving the interest of power to contain the subversions it encountered in different forms. We also suggest that both narratives exploit the discursive forms (literary and nonliterary) of the particular era where they are recorded.
\end{abstract}

Keywords: Cold War, containment, Islamization, Islamophobia, orthodox texts, subversion

\section{Introduction}

Islamization and Islamophobia are two political narratives that served the interests of power (West) during and after the Cold War in combating the Soviet Union in the East and the rise of Muslim influence in the West, respectively (Akbar, 2017; Paracha, 2018; Report, 1997; Zunes, 2018). According to Foucault, power holds an omnipotent status and is present everywhere, "...not because it embraces everything, but because it comes from everywhere" (Foucault, 1981: 93). In this regard, the investigation of this highly augmented, rather exaggerated status of power in the promulgation and propagation of the political narratives of Islamization and Islamophobia garners wider critical attention. But in the field of literature, particularly in the case of Pakistani Anglophone fiction (Banerjee, 2020; Langah, 2019; Morey, 2018; Quin, 2018; Riaz, 2017; and Haidar, 2012), most of the studies escape from exploring the influence of power (West) on the literary and 
non-literary discourses in its effort to promulgate and propagate the narratives of Islamization and Islamophobia with particular reference to the Cold War politics.

The paper aims at reading Muhammad Hanif's (The British Pakistani writer and Journalist) and Hanif Kureishi's (the playwright, screenwriter, novelist, and film director) selected novels to examine the 'textualization and historicization' of the political narratives of Islamization and Islamophobia (Montrose, 1997). Adopting the theory of New Historicism, we aim at examining the way the "orthodox texts" helped power to promulgate the written narratives (Greenblatt, 1981: 41). For this purpose, two novels by two different authors (British Pakistani and British) were selected and examined in the backdrop of the actual political narratives of the time of publishing or setting of the two novels. As such, Hanif's $A$ Case of Exploding Mangoes (2007) was examined in the backdrop of the politics of Islamization and the Cold War, whereas Kureishi's The Black Album (1995) was probed in accordance with its relation to the post-Cold War politics of Islamophobia. Overall, the current study is twofold: (1) showing the shift in the West's treatment of Muslim identity before the end of the Cold War and its aftermath, and (2) investigating the way(s) the contemporary Pakistani Anglophone literature has been responding to it.

Islamization in Pakistan started during the last decade of the Cold War era by the despotic regime of General Zia (1977-88). Along with the promotion of mosques/Madrasa culture, and the political empowerment of Islamic scholars, Jihad culture also found its abode in the country. Critics believe that this Islamization was political in nature as it was inclined towards the promotion of Jihad culture and Talibanization in Pakistan and Afghanistan for the sake of military and monetary benefits from America (Paracha, 2018) as well as to defeat Russia in Afghanistan. In other words, it was America's direct involvement in the manipulation of Islam's concept of Jihad that institutionalized Islamic extremism in Pakistan. However, the West's (America and other capitalist allies) initial support of Muslim identity as in the case of Islamization of Pakistan during the Cold War era, and later its enmity with it — in the form of Islamophobia-makes it a good site and locus of power-politics un/making similar but self-contradictory policies for its own interest. The West's policy with pre-9/11 Muslims of South Asia and the Middle East as brothers and post-9/11 Muslims as terrorists, therefore, requires a critical examination of the Cold War power politics in connection with Islamization in the particular countries that, concurrently, contributed at large to the rise of Islamophobia all over the world. The Runneymede Trust's report about Islamophobia titled "Islamophobia: A Challenge for Us All" (1997) collects this same shift in Western attitude towards Muslims as:

It is no accident, some commentators have suggested, that the recent demonizing of Islam began at much the same time that the "evil empire" of communism receded as a real threat. The western political and popular culture required a new enemy, an implacable other, to replace the Soviet Union. Also, it is cynical if plausibly claimed, the Western armaments industry needed a new enemy (p. 8). 
In literature, different authors have presented different readings of Islamization and Islamophobia in different crucial political eras. This is significant in investigating contemporary literary works. Nukhbah Taj Langah (2019), for instance, reads Islamization and post-9/11 Islamophobia through Pakistani literary and non-literary responses. She endeavors to do two things in her work. First, she "...deconstructs and connects Islamization and Islamophobia as two key processes which impacted Muslim-Pakistani identity in the aftermath of 9/11..." (p. 79), and second is that she challenges the "...repetitive reliance on fiction for understanding the post-9/11 discourse..." (Langah, 2019: 80). Although Langah (ibid) attempts to study Islamophobia in the contemporary Pakistani literature by linking it with Islamization in Pakistan, none of the two aspects of her research deals with the role and contribution of the literary and non-literary discourses in the construction of the narrative of Islamophobia. Similarly, Humaira Riaz (2017) studies racism and islamophobia in the selected American literary texts. She uses 'Fredrickson's notion of racism "as scavenger ideology", and "unveils racism incorporated in Islamophobia in fiction" (ibid: 7). By so doing, she also escapes from exploring the actual role of discursive formations in the construction and development of Islamophobia.

In his seminal book titled Islamophobia and the Novel, Peter Morey (2018) discussed the impact of Islamophobia on the contemporary Anglophone novel. Drawing on the critiques of some of the cutting-edge theorists such as Theodor Adorno, Edward Said, and Gayatri Chakravorty Spivak, he examined Islamophobia in the novels. Besides three English writers including Martin Amis, Ian McEwan, and John Updike, Morey (2018) criticized five Pakistani writers in his monograph including: Hanif Kureishi, H. M. Naqvi, Nadeem Aslam, Kamila Shamsie, and Mohsin Hamid. He established the relationship between Islamophobia and the powerful politics of the West and its subsequent representation in the contemporary novel. Despite its undeniable coverage of the problem of Islamophobia with reference to the contemporary novel, the study still has some limitations. The selected texts have not been examined in the backdrop of actual political discourse produced during the time of their production. In summary, Morey's study seems to be un-skeptic about power's control over the literary and non-literary discourse.

The present research highlights on the contemporary Pakistani Anglophone fiction with particular reference to the actual non-literary (political) discourse are also missing in the ongoing debates about Islamophobia as (Banerjee, 2020; Langah, 2019; Morey, 2018; Quin, 2018; Riaz, 2017; and Haidar, 2012) claim. Tackling the dichotomy between Islamization and Islamophobia suggests a huge research gap in contemporary Pakistani literature. We, subsequently, believe that there is an urgent need for research that views both narratives in their historical perspective to understand aptly the role of power ${ }^{1}$ in their construction and development. In order to fill this gap, we rely on the critique of Stephen Greenblatt. In his viewpoint, power uses "orthodox texts" to promote and promulgate a particular ideology to construct ideological selves that safeguard its interests to contain the subversion it comes across (1981: 41). We, therefore, examine the 
discursive formations (both literary and non-literary) about Islamization and Islamophobia to unveil the hidden power-politics.

\section{New Historicism as a Reading Method}

Providing the preamble for the theory of New Historicism, Michel Foucault (1981: 93) confirms that "[p]ower is everywhere; not because it embraces everything, but because it comes from everywhere". Greenblatt (1981) borrows this notion of power from Foucault and contends that power's autonomy and pervasiveness depends upon its ability to contain any kind of subversion it comes across. He uses different words for subversiveness: in some cases, he considers them "other voices" and in others, subversiveness appears to be "alien voices" for him (1981: 43and 45). But whatever word or expression he uses to define subversiveness, it has one common characteristic which is its opposition with power. Subversiveness is always attacked to be contained and undermined and to be tamed following "our own sense of truth and reality" (Greenblatt, 1981: 52). For him, subversion is a confrontation with the normative structure, which is driven primarily by power, because "the simple operation of any systematic order, any allocation method, will inevitably run the risk of exposing its own limitations, even (or perhaps especially) as it asserts its underlying moral principles" (ibid: 51).

Furthermore, the exposure of subversion comes at the most intense moments when any narrative, ideology, or "the moral value of a particular form of power is not merely assumed but explained (ibid). Nevertheless, Greenblatt's discussion and definition of 'subversion', where he accords it a contesting place with the normative, considers it a very condition of power. In response to the puzzle that power produces its own subversion and then contains it, Greenblatt himself asserts:

But why, we must ask ourselves, should power record other voices, permit subversive inquiries, register at its very center the transgressions that ultimately violate it? The answer may be in part that power, even in a colonial situation, is not entirely monolithic and hence may encounter and record in one of its functions materials that can threaten another of its function; in part that power thrives on vigilance, and human beings are vigilant if they sense a threat; in part that power defines itself in relation to such threats or simply to that which is not identical with it (p. 50).

Having realized that the radical and disturbing nature of subversion-that can threaten any power-driven normative or ideology-power produces it and treats it as a thing that "furthers its ends" (p. 48). In 1998 John Brannigan (1998) also comments on this aspect of subversion in association with the role of power to the society in the first place. He argues that society can check and regulate the deviation that makes the containment possible by appropriating it according to the normative reality. In addition, "[p]ower depends upon subversive beliefs to reinforce its constructions of reality and normality", and that it "can only define itself concerning subversion, to what is alien or other, and at the heart of power is, therefore, the production and subsequent containment of subversion (p. 64).

Like subversion, the other aspect of the New Historicist criticism that Greenblatt introduced is the notion of "fashioned self". It is built on the premise 
that the subversion is contained by the power with the help of linguistically and ideologically constructed selves. In his book Renaissance Self Fashioning: From More to Spencer, Greenblatt (1980) suggests that the ideological selves, once created, control and direct their own social and political behaviour by complying with the dominant ideology as well as by keeping a watch on its flow. Ideologically, this excludes the role of coercive force. Since, "there are always selves-a sense of personal order, a characteristic mode of address to the world, a structure of bounded desires - and elements of deliberate shaping in the formation and expression of identity" (p. 1). There is a strong role of the state, family, and religious institutions in shaping the identity of the middle class as well as the aristocratic strata of any society. And the sole reason for power that can assert itself in the form of different social institutions, i.e., state, family, religious groups, is to impose the identity of its interest on its subjects. So,

[i]f we say that there is new stress on the executive power of the will, we must say that there is the most sustained and relentless assault upon the will; if we say that there is new social mobility, we must say that there is a new assertion of power by both family and state to determine all movement within the society; if we say that there is a heightened awareness of the existence of alternative modes of social, theological, and psychological organization, we must say that there is a new dedication to the imposition of control upon those modes and ultimately to the destruction of alternatives (pp. 1-2).

While putting it differently, Greenblatt's critique of self-fashioning accords the 'self' the status of a puppet in the hands of power, which is so pervasive that it can hegemonize even the will and identity of any of its subjects. Interestingly, he views this fashioning of the 'self' that in our opinion is no different than 'hegemonizing of the self', as a "manipulable, artful process" (p. 2). This 'manipulable and artful process', in turn, shapes and reshapes the 'self' in its entirety, generating from the practices of parenthood and teaching, manners to demeanours, the notions of hypocrisy to deception, the 'self' acquires a new reality that can be spotted in the representation of its nature, speech, and actions. At this point, Greenblatt returns to literature. Since the critique of New Historicism itself does not differentiate between literature and context and text and co-text, the basic notion of 'self-fashioning' is based on the elimination of the distinction between social life and literature. More clearly, "[i]t invariably crosses the boundaries between the creation of literary characters, the shaping of one's own identity, the experience of being moulded by forces outside one's control, the attempt to fashion other selves" (p. 3), and that "[1]iterature functions within this system in three interlocking ways: as a manifestation of the concrete behaviour of its particular author, as itself the expression of codes by which behaviour is shaped, and as a reflection on those codes" (p. 4).

Social action and its representation are also embedded and grasped in the "public signification" even by the ones who create that representation as well as the ones who interpret it (p. 5). Therefore, it is important to place the text within its social context to see the way the language of a text treats a particular public 
signification (ideology) and then contributes to the fashioning of the self. Greenblatt states that "[1]anguage, like other sign systems, is a collective construction; our interpretive task must be to grasp more sensitively the consequences of this fact by investigating both the social presence to the world of literary text and the social presence of the world in the literary text" (p. 5).

To sum up, self-fashioning stands for a complying self that does not require any formal or policing institution to submit to an "absolute power or authority" (p. 9). It is achieved "in relation to something perceived as alien, strange or hostile", to which Greenblatt calls the "threatening Other" that "must be discovered or invented in order to be attacked or destroyed" (ibid: 9). In this part of the discussion, it is likely that the notion of "threatening Other" in self-fashioning and the notions of 'subversion' and 'alien other' seem to be the same, as both subvert from the normative and are considered to be a threat for it. Greenblatt (1980) says:

The alien is perceived by the authority either as that which is unformed or chaotic (the absence of order) or that which is false or negative (the demonic parody of order). Since accounts of the former tend inevitably to organize or thematize it, the chaotic constantly slides into the demonic, and consequently, the alien is always constructed as a distorted image of the authority (p. 9).

Nevertheless, the containment of the "threatening Other" or "alien other" is made possible with the help of language that helps power promulgate a particular narrative which, in turn, produces the linguistically and ideologically constructed selves, "Self-fashioning is always, though not exclusively, in language" (ibid). John Brannigan (1998: 7) also adds:

The self polices and regulates its own desires and repressions. This removes the need for power to be repressive. No physical or military force needs be deployed or exercised for power to have operated effectively in the interests of dominant ideological systems when the self, ideologically and linguistically constructed, will reproduce hegemonic operations.

In his effort to contain the subversion with the help of language, as discussed above with reference to Invisible Bullets, Greenblatt indicates that power produces subversive insights within the orthodox texts to destroy that 'alien other' it confronts, and to "furthers its ends" (Greenblatt, 1981: 48). In the process of doing so, he asserts - in his critique of 'self-fashioning' - that "the power generated to attack the alien in the name of the authority is produced in excess and threatens the authority it sets out to defend. Hence, self-fashioning always involves "some experience of threat, some effacement or undermining, some loss of self" (Greenblatt, 1980: 9). He mentions later in his essay Invisible Bullets that the 'orthodox texts' display work to contain the subversions while complying with a particular political narrative or ideology, and at the same time they provide the reader with an otherwise view of subversive insights. Clearly enough, "the identification of the orthodox ideology that informs a particular text by no means obviates the possible presence of genuinely subversive elements-that is, the element that can be understood to be subversive, either by ourselves or by a reader 
who lived surrounded by institutional expression of that ideology" (Greenblatt 1981: 42).

In an attempt to revalidate Greenblatt's scholarship of New Historicism in the selected context, this study is built on one major question which reads: Does power rely on the political and literary discourse to promote and promulgate the narratives of Islamization and Islamophobia to contain the subversions it came across in the form of communism and the rise of Muslim influence in the West? The paper aims at positioning the shift in the Western treatment of the Muslim identity in the case of Islamization and Islamophobia against the backdrop of Cold War politics in the contemporary Pakistani Anglophone fiction on one hand and suspects the discursive formations (literary and non-literary) of that particular era in which both the narratives found their heyday. In addition to this, the study also aims at examining the way both narratives aided power to contain the subversions it confronted in the form of communism in Muslim countries and the rise of Muslim influence in the West. By doing so, it will also enable the readers to connect Cold War politics, Islamization, and Islamophobia with the contemporary Pakistani Anglophone fiction in the backdrop of the actual political discourse of the particular period. In summation, the identification of the orthodox ideology of Islamization in Pakistan and Islamophobia at the international level within the "orthodox texts"as Greenblatt (1981: 41) puts it - is the prime focus of this study. It also strives to unveil the subversion that power (as represented by the West) confronted in the form of communism during the Cold War era and the rise of Muslim influence in the West in the post-Cold War era.

\section{Procedure and Corpus}

We analysed the selected contemporary Pakistani fiction in the backdrop of the actual political discourse about Islamization and Islamophobia to examine the way the political discourse about Islamization and Islamophobia complies with the dominant narrative as set by power, and to show the way the contemporary Pakistani Anglophone fiction responds to it. By doing so, the paper does not only test Stephen Greenblatt's scholarship that power uses orthodox texts to contain the subversion but also reveals the politics behind both narratives by highlighting a shift in West's treatment of Cold War and post-Cold War Muslim identity.

The corpus of the study has been selected based on its relevance with the narratives of Islamization and Islamophobia. The literary text that has been selected for the construct of Islamization is A Case of Exploding Mangoes by Muhammad Hanif. The reason behind the selection of this novel is imbued in its distinctive encapsulation of the era of Islamization pertinent to Jihad in Afghanistan against Russia and Cold War politics. Albeit there exist other works such as Uzama Aslam Khan's The Geometry of God (2008) and Kamila Shamsie's Broken Verses (2005) that touch the troubled issue of political Islamization in Pakistan, their treatment of the very construct of Islamization regarding Cold War politics is extinct. Similarly, in the case of Islamophobia, Hanif Kureishi's The Black Album (1995) holds an eminent place. Its textualization of Rushdie Affair in England followed by violent street protest and the Western hostility towards Muslims makes it the most 
appropriate work to examine the politics of Islamophobia in the post-Cold War scenario.

Holding on the same relevance with the narratives of Islamization and Islamophobia, those non-literary (political) texts were selected which showed explicit support of the power for these two narratives during and after the Cold War era. For example, the selected biography of the then military ruler of Pakistan Shaheed-ul-Islam Zia-ul-Haq (1990) by Saleem Azam along with the selected excerpts from Western newspapers shows explicit support of power for the movement of political Islamization in Pakistan. On the other hand, Runnymede Trust's report about Islamophobia entitled Islamophobia: A Challenge for Us All (1997) was selected to show how the same Muslim identity that was supported by the West during the Cold War era turned out to be a hostile entity in the post-Cold War era.

In sum, the study of these selected texts and co-text, against the backdrop of the aforementioned critique of power, subversion, and containment by Greenblatt, will not only show the way this shift in the Western treatment of the very Muslim identity is registered by the contemporary Pakistani Anglophone fiction but will also display the way it responds (complies/subverts) to it.

\section{Cold War Politics of Islamization: A Case of Exploding Mangoes (2007)}

Being set in 1988, the novel spans eleven years of Gen. Zia's despotic regime (1977-1988). It re-creates the history of Cold War politics while providing a fictionalized account of the Pakistan-Saudi-American nexus against Russia in Afghanistan. Besides fore-fronting Zia's unilateral political policies such as Huddood Ordinance, political victimization, religious discrimination, and ultimately his death in a plane Crash, the novel also provides an account of the political Islamization of Pakistan akin to the promulgation of the narrative of Jihad and its direct involvement in the Afghan war in coalition with America. It reveals the way the politics between communism and capitalism was fought on the pretext of the narrative of Islamization in Pakistan and Afghanistan. In Greenblatt's words, it represents "social energies" about the causes and effects of political Islamization in Pakistan. In what way do these social energies-as depicted in the literary discourse of Pakistan-respond to the political narrative of Islamization in Pakistan? is the most relevant question. Basically, Greenblatt focuses on "...the process whereby subversive insights are generated amid apparently orthodox texts and simultaneously contained by those texts, contained so effectively that the society's licensing and policing apparatus is not directly engaged" (Greenblatt, 1981: 41). Assuming Hanif's A Case of Exploding Mangoes as an 'orthodox texts', we examined the way it deals with the political narrative of Islamization, and we speculated the way it contains the subversion (if at all) that the power confronted in the form of liberalism or secularism in Pakistan. For this purpose, we examined Hanif's novel in the backdrop of General Zia's biography Shaheed-ul-Islam Zia-ulHaq (1990) and various other local and international newspaper articles that were published during and after the Cold War. We did not excavate only the influence of power in canonizing the literary and political discourse but also highlighted the 
possibility of subversion even on the part of these orthodox texts (literary and political).

In an essay about Zia (1990), the leader of Pakistan's largest political party and the three-time elected Prime Minister of Pakistan, Mian Muhammad Nawaz Sharif, glorifies his state policies and calls him a true patriot and a great servant of Islam. In the selected biography, Sharif is not alone posing himself to be pro-Zia polices. Still, there are others (politicians and religious scholars) who view the political Islamization in Pakistan as an old promise that had to be started even at the time of partition in 1947 because Pakistan was found on the very narrative and identity of Islam. For example, Mufti Taqi Usmani (1990), a renowned Islamic scholar, notes that Pakistan was found in the name of Islam: "The Basic purpose for its separation from India was to establish a state where its Muslim citizens could order their lives in accordance with Islamic teachings" (Usmani, 1990: 59). He did not only highlight the historical basis and needs for Islamization but also reported the steps taken by Zia to realize the dream of an Islamic country. This support for Islamization within Pakistani politicians and scholars is understandable due to the very slogan on which Pakistan came into existence: 'Pakistan ka matlab kia? La illa ha il Allah!' (Literal: What is the meaning of Pakistan? There is no God, but Allah!). It is interesting to mention similar support for Islamization in Pakistan by the West, especially America and its other capitalist allies. In an article published in the Time Magazine (1990), one can easily notice overt support for Zia's Islamization program: "In general Zia's Islamization programme - as in those of many of his Muslim fellow rulers - piety, patriotism, and opportunism were equally joined. He was a devout Muslim, shocked by the moral deterioration of Pakistani society like corruption, drug addiction, and violence spread. He saw Islam as a means of restoring moral fibre to Pakistani society" (Times 1990: 140).

Likewise, we realize that Gordon Brook-Shepherd (1990) - an English journalist and intelligence agent - is casting his vote in favour of Zia's Islamization in Pakistan in the Sunday Telegraph. Quite opposite to the contemporary antiMuslim narrative (Islamophobia), he considers Islam as a great source of cultural harmony and, therefore, finds it as the only solution to "hold Pakistan's tribal patchwork together and also keep soviet communism at aby along his Afghan borders" (Brook-Shepherd 1990: pp. 145-146).

It is interesting to view the Western political commentators' positive inclination towards a religion that is being censured severely by the Western gaze in today's world of Islamophobia. Different studies have revealed that Islamophobia stroke the chord in the West right after the end of the Cold War, due to the fact that the West no longer needed it in the post-Cold War context. Runnymede Trust's report excavates that "the recent demonizing of Islam began at much the same time that the "evil empire" of communism receded as a real threat. Western political and popular culture required a new enemy, an implacable other, to replace the Soviet Union" (Report 1997: 8). In this context, we suggest that the narrative of Islamophobia should be taken as a continuation of the Western political interest but in opposite direction. However, sticking to the focus of this section, which is to examine the inclination of discursive formations towards the power 
generated narrative of Islamization, we believe that the political Islamization in Pakistan, which started at first place by the despotic regime of Zia, was backed and supported largely by the Western political discourse because of its stakes in Afghanistan. The situation, thereby, confirms Greenblatt's proposition of 'orthodox texts' that views the discursive formations serving the interests of power, by containing the subversions it comes across (Greenblatt, 1981).

In contrast to the political narrative as reflected in the political discourse about Islamization, contemporary Pakistani fiction seems to be subverting from the narrative of political Islamization in Pakistan. A Case of Exploding Mangoes by Muhammad Hanif contradicts the heroic image of Zia and portrays him as a moron who tries to entertain his friends with his rusted sense of humour. Unlike his political title of "Shaheed-ul-Islam" (Literal: Martyr of Islam (Azam, 1990)), he is portrayed as an ordinary man who is impregnated with the lust for power, fame, and the fear of death. A man who wants to be considered for the "noble peace prize" (Hanif 2008: 31) [Text 1] for defeating Russia in Afghanistan at the cost of Talibanization and radicalization of his own country on the pretext of Jihad culture and Islamization. Quite contrary to the extravagantly pious image of Zia as created by Brook-Shepherd (1990), Times (1990), and Sharif (1990), Hanif portrays him as a Muslim "whose understanding of religion didn't go beyond parroting what he had heard from the next mullah" (Hanif, 2008: 41) [Text 2]. In the novel, a fine example of his understanding of religious matters appears in the very first meeting he calls right after his military coup. Instead of discussing the matters of governance, the first order he passes is to remove all the words that are used alternatively with the word Allah: "All God's names were slowly deleted from the national memory as if a wind had swept the land and blown them away. Innocuous, intimate names: Persian Khuda [...] Rab [...] Maula [...] Allah had given himself ninety-nine names. His people had improvised many more. But all these names slowly started to disappear" (Hanif, 2008: 44) [Text 3].

Instead of giving the Islamization during Zia's era any religious outlook, the novel excavates its hidden connection with the politics of the Cold War as well as textualizes the power-politics that encircled that era. In the novel, the reader finds an overt use of religion card in the ongoing power-politics of the Cold war against Russia. The use of religion card against Russia is evident when Zia flies to Lufkin Texas to raise funds for Afghan Jihad. He considers it a sacred expedition for which "no principle was sacred enough" (Hanif, 2008: 118) [Text 4]. As he plans his speech for the evening, he notes: "Islam, Christianity . . forces of good, communism evil (use the word godless)" (Hanif, 2008: 121) [Text 5]. Hence, the novel does not only textualizes Zia's alliance with America in the Cold War, but it also unveils the exploitation of religious narrative in the name of Islamization and Afghan cause. S. Akbar Zaidi (2017) describes this fusion of religion and politics in the name of Islamization during Zia's dictatorial rule as: "[T]his Islamization, supported by a severe despotic, military dictator, led to the rise of Islamists . . His tenure saw the state-sponsored export of Islamic jihad to several parts of the world" (p. 4). Like this contemporary interpretation of Zia's Islamization program by Zaidi (2017), the novel also attempts to satirize it and to unravel the politics behind it. 
The reader identifies this aspect of politics when he reads Zia's thoughts of altering the maxim of Jinnah (father of Pakistani nation) "Unity, Faith, and Discipline" (Hanif, 2008: 105) [Text 6]. He thinks that "[t]he slogan. . had to go", and that "Allah has to be there. Jihad, very important...it would please...Bill Casey" (ibid). Likewise, as the story proceeds, the frequent "informal visits" (Hanif 2008: 86) [Text 7] of Prince Naif from Saudi Arabia to Pakistan and their subsequent friendly get-togethers with Bill Casey (the CIA chief), indicates the Pak-Saudi-America nexus in their collective struggle against the Soviet Union on one hand, and mocks, on the other, the Muslim countries like Pakistan and Saudi Arabia's susceptibility for polluting the holy cause of Jihad by playing puppets in the hands of Western Capitalist during Cold War. The novel portrays Bill and Prince Naif as ilk of the same tribe who love to enjoy and party during the toughest time of war while "racing their planes from Saudia to Pakistan" as their favourite hobby (ibid).

The novel also textualizes America's sudden financial withdrawal from Afghanistan, right after Russia's retreat, and the subsequent abandonment of its dollar-fed mujahideen. It satirizes the event of Afghan-cause desertion by portraying the much-celebrated hero of the cause (Osama bin Ladin) as an unacknowledged and unrequited soldier. In the novel, the encapsulation of this political event is evident during the celebration of American Independence Day which is organized by the Zia fraternity in Pakistan. Although the theme of the evening is named as Afghan culture, but the cold-shouldered behaviour of the CIA towards the actual soldiers (Afghan Mujahideen) of Afghan war forecasts regions instability as well as peace issues. For example, $O B L$ (Osama Bin Laden), the chief of Afghan Mujahideen, can be seen wandering like an uncelebrated hero. Expecting a warm welcome, he can be seen as raising "his hand as if he wasn't identifying himself to a party usher, but greeting an invisible crowd" (Hanif 2008: 262) [Text 8 ]. He even has to introduce himself to the duty sergeant as "Of laden and Co. Constructions", who after verifying his name from the list of guests allows him to proceed to the venue (ibid). Hanif portrays a situation in which the main key player of the Afghan cause "OBL was forgotten" and the "American agencies were trying to take the credit for the victory" (ibid). Hence, the discontented victor $O B L$ is represented as striding after recognition, from person to person, and from one journalist to another. After all this humiliation, he meets the character of General Akhtar who is Zia's second in command and the chief of Inter-Services Intelligence (Pakistan's intelligence agency). He greets him and acknowledges him as: "We would never have won this war without our Saudi friends", to whom he reveals the evil motives behind the narrative of Jihad and terms it as a construction business: "There is no business like the construction business in times of war" (Hanif, 2008: 265) [Text 9]. To put it differently, OBL's humiliation at the event and his assertion about the wartime business, textualizes and refers to Zia regime's acquisition of financial and military aid from America during the Cold War, refers to the selfrealization of Afghan jihadis that the war is over now, and it is the time to go back home or to search for new "Construction businesses".

As the novel proceeds, the reader also becomes acquainted with Zia's control of the flow of information in the country. The abduction of national media discourse 
by the despotic regime has been aptly represented in the novel. For instance, in the story, $\mathrm{Zia}$ is portrayed as the one who is controlling the national press through his corrupt Information Minister who possesses a fake MBA degree and whose prime job is to handle the editors of newspapers by whatever means possible: "he found out that they were the kind of intellectuals who prayed with him devoutly then rushed off to get drunk in the hotel rooms that his government provided them" (Hanif, 2008: 113) [Text 10]. Succumbing to the influence, the press portrays Zia, as the "soldier of Islam" (Ibid), and pronounces him as a fighter who is fighting an ideological war in Afghanistan. The narrator of the novel asserts that the editors of the national newspaper, directed by the gaze of power, strive hard to please their master in uniform. On one occasion in the novel, the narrator says:

The nation's press had finally shown some spark. The editors had used their imagination while reporting his speech. Every newspaper had it as the banner headline. The message had gone out loud and clear. 'The Battle for Our Ideological Frontiers has begun.' He was particularly pleased with the three-picture strip idea that the Pakistan Times had come up with to illustrate the main points from the extempore part of his speech. First of all, I am a Muslim was the caption under a picture of him draped in a white cotton sheet with his head reclining on the black marbled wall of Khana Kaaba in Mecca. Then I am a soldier of Islam appeared under his official portrait, in which he was wearing his four-star General's uniform (Hanif, 2008: 113) [Text 11].

At this point, the novel does not only highlight the manipulation of media discourse but also confirms Greenblatt's notion of orthodox texts that are utilized by the power to contain the "subversive insights". "Textualizing and historicizing" the Cold War era and Islamization in Pakistan, the novel problematizes the Islamization of Pakistan during Cold War on one hand, and forefronts the powerplay of narratives and ideologies on the other. Approaching the novel with Greenblatt's notion of orthodox texts (literary and non-literary), we suggest that the literary discourse on Islamization in Pakistan, with particular reference to A Case of Exploding Mangoes by Muhammad Hanif, does not comply with the politically driven narrative of Islamization. Rather, it unravels the political imbroglios operative underneath the very slogan of Islamization.

\section{Post-Cold war Politics of Islamophobia: A Case of The Black Album (1995)}

As substantiated above in the case of Islamization in Pakistan in the previous section, Western (America and the other capitalist countries) gaze towards the very 'Muslim identity' was polite and friendly during the Cold war. Surprisingly, the subsequent era, i.e., the post-Cold War era, witnessed a proliferation in the antiMuslim sentiments in the West. Runneymede Trust's report about Islamophobia titled 'Islamophobia: A Challenge for Us all', published in 1997, views this change in the Western treatment of Muslim identity as a change in Western political interests:

It is no accident, some commentators have suggested, that the recent demonizing of Islam began at much the same time that the "evil empire" of 
communism receded as a real threat. The western political and popular culture required a new enemy, an implacable other, to replace the Soviet Union. Also, it is cynical if plausibly claimed, the Western armaments industry needed a new enemy (Report 1997: 8).

While highlighting the shift between two different narratives that are encircling around the same religious identity, we revealed the contradictory approach of the West towards Islam. The friendliness towards Islam, as maintained by Shepherd (1990), in the case of Islamization, that Islam was a great source of harmony and, therefore, the best antidote of communism during the Cold War era, turns out to be 'other', 'inferior', 'enemy', and 'manipulative', according to Runneymede Trust's report, in the post-Cold war context. The situation thereof suggests the involvement of the West in both of the narratives, i.e., Islamization and Islamophobia. Since Greenblatt asserts that power uses "orthodox texts" to deploy a particular narrative, we investigated the way texts responded to the narrative of Islamization during the Cold War era. In this section, we aim at examining the way the orthodox texts about Islamophobia responded to the notion of Islamophobia. For this purpose, we have examined Hanif Kureishi's The Black Album (1995) in the backdrop of the actual political discourse as reported in the report Islamophobia: A Challenge for Us All (1997). This anti-Muslim political discourse views Muslims' identity as: "Islam as monolithic and static"; "Islam as the other"; "Islam as inferior"; "Islam as an enemy", and "Muslims as manipulative". Just like the reading of Muhammad Hanif's A Case of Exploding Mangoes in the backdrop of the political narrative of Islamization, the reading of Kureishi's novel did not only reveal the way the selected novel 'complies to' or 'responds to' this political narrative of Islamophobia but re-validated Greenblatt's critique of orthodox textsthat contain the subversions by promoting a narrative-driven by power-within the context of Islamophobia too.

The first impression of Muslims that the Runnymede Trust's report hints at is the fact that the Western political discourse viewed Islam as a monolithic and static bloc that is hostile towards any kind of cultural diversity. It was depicted to be an "undifferentiated, static and monolithic" bloc that is "intolerant of internal pluralism and deliberation" (Report 1997: 5). A religion that has tensions with the West as well as within its own followers, who simultaneously ignore "debates about human rights and freedoms in Muslim countries and contexts, and between Islam and secularism" (ibid). Interestingly, reading The Black Album in the background of this political narrative, the reader comes across numerous instances where the characters, who consider themselves to be devout Muslims, seem to be having mutual tensions with various religious matters. The first tension appears about the legitimacy of being an accountant because it involves interest payments. The character of Hat who is studying accountancy, is censured by Chad for studying something that is forbidden: "[A]ccountants have to meet many women. And shake hands with them. They expected, too, to take alcohol every day and get involved in interest payments" (Kureishi, 1995: 91) [Text 1]. Similarly, there appears another Muslim character Shahid who supports studying accountancy and persuades Hat to continue his education because for him "there must be more to living than 
swallowing one old book [...] What men and women do, and the things they make must be more interesting than anything that God is supposed to do" (Kureishi, 1995: 272) [Text 2]. There appear other instances where the intra-religious tensions among the rows of Muslims become more obvious. For example, the old debate about the issue of gender discrimination appears in the conversation between Tahira and Chad. The reader witnesses another aspect of intra-religious tension which is about the proper way of dressing. Their conversation gives an impression of tense relation between Muslim men and Muslim women in which both parties are showing little respect to each other. Tahira objects on Chad's trousers saying, "You brothers urge us to cover ourselves but become strangely evasive when it comes to your own clothes. Can't you wear something looser? [...] aren't you thinking of growing some beard? (Kureishi, 1995: 105) [Text 3].

The second impression that the Western political discourse of Islamophobia accorded to Muslims in the post-Cold War and the pre-9/11 era was that Islam is the other. It was viewed as a religion that in Greenblatt's words "an alien other" (1980: 3) preaching exotic kinds of ideologies and practices and has no inclination to absorb or mix into any other culture. According to the Runnymede Trust's report, "Islam is 'other', with few or no similarities between itself and other civilizations and cultures, and with few or no shared concepts and moral values" which is "hermetically sealed off from the rest of the world, with no common roots and no borrowing or mixing in either direction" (1997: 6). On the other hand, in The Black Album, Riaz and Chad seem to be advocating a religion that is actually "an alien other". With their radical and fundamentalist understanding of Islam, they create such an image of Islam which is proud of its own ideology to the extent that it has no regard for any other culture or civilization, and, therefore, "no capacity to mix or absorb" (Report 1997: 6). Chad says: "They are existing at the lowest level! And we think we want to integrate here! But we must not assimilate, that way we lose our soul. We are proud and we are obedient. What is wrong with that? It's not we who must change, but the world!" (Kureishi, 1995: 81) [Text 4].

The third important finding of Runnymede Trust's report is that the Western political discourse about Islamophobia considered Islam an inferior religion. As portrayed by the Western media, the difference between Islam and the West is the difference between civilized vs uncivilized, and rational vs irrational. Runneymede Trust's Report confirms that Islam was portrayed as "civilized, reasonable, efficient, sophisticated, enlightened, non-sexist", whereas Muslims are portrayed to be "primitive, violent, irrational, scheming, disorganized and oppressive" (1997: 6). On the other hand, the novel no doubt highlights the same Western bias towards Islam with the help of its English characters such as the character of Professor Brownlow who considers Riaz "[t]he slave of superstition [...] existing in an imaginary realm ruled by imaginary beings", and thinks that it is "Wonderful to have all rules of life delivered from on high. What to eat. How to wipe your bottom [...] how abhorrent too!" (Kureishi, 1995: 97) [Text 5]. But the novel's portrayal of Muslims as irrational and primitive is still problematic. The aubergine episode in the novel affirms Muslims to be primitive, irrational, and superstitious who can worship even a vegetable if they find any resemblance of holy inscription in it: "He 
told them that a devout local couple had cut open an aubergine and discovered that God had inscribed holy words into the mossy flesh. Moulana Darapuria had given his confirmation that the aubergine was a holy symbol" (Kureishi, 1995: 171) [Text 6].

The fourth point that the report makes clear is that the West thinks about Islam as its enemy. Based on the assumptions of irrationality, oppression, and violence, Western political discourse viewed Islam as a religion that is "violent and aggressive" and "firmly committed to barbaric terrorism, and implacably hostile to the non-Muslim world" (Report, 1997: 7). In The Black Album the Muslim characters' usage of violent and aggressive expressions, such as "[w]e are going for the wrath" (Kureishi, 1995: 87) [Text 7], and that "We should call ourselves the Foreign Legion" (Kureishi, 1995: 82) [Text 8], seem to be complying to the antiMuslim political discourse that viewed Muslims "firmly committed to barbaric terrorism" (Report, 1997: 7). Moreover, Riaz's assertion that "[w]e are not blasted Christians. We don't turn the other cheek. We will fight for our people who are being tortured in Palestine, Afghanistan, Kashmir! War has been declared against us. But we are armed' (Kureishi, 1995: 82) [Text 9], which can also be considered a continuation of the narrative that was upheld by the West in the post-Cold War context.

Similarly, the fifth and the last aspect of the anti-Muslim political narrative imagines Muslims as manipulative: "It is frequently alleged that Muslims use their religion for strategic, political and military advantage rather than as a religious faith and as a way of life shaped by a comprehensive legal tradition" (Report, 1997: 8). In the novel, Riaz's strategic communal gatherings and the reiterative speech titles of his addresses, "Islam: A Blast from the Past or a Force for the Future" and Democracy is Hypocrisy" (Kureishi, 1995: 80) [Text 10], seems to be complementing that aspect of the Western political discourse about Islamophobia that imagines Muslims to be manipulative, strategic and the ones always seeking 'political and military advantage'. However, the analysis of The Black Album (1995) in the backdrop of the Western political discourse about Islamophobia as published by The Runnymede Trust's report reveals its inclination towards the narrative as generated by power (the West). Apparently, it also confirms Stephen Greenblatt's notion of "orthodox texts" that are always compliant to power, always justifying and solidifying its stance. But, at the same time, the novel reveals Western bias towards Islam and Muslims cloaked in the reiterative theme of racism. The English characters such as Professor Brownlow, Deedee Osgood, and Jump are good candidates in this regard.

\section{Conclusion}

Power's contribution to the development of the narratives of Islamization and Islamophobia in the light of Greenblatt's scholarship of orthodox texts (texts and co-texts) was viewed. We observed that in both cases, i.e., Islamization and Islamophobia, power relied heavily on the political discourse to promulgate its respective narrative. As to the case of Islamization, the West again resorted to the politically driven anti-Muslim narrative to demonize Muslim identity to contain the 
subversion it confronted in the form of the rise of Muslim influence in the Western countries. In Brannigan's words, it created "linguistically and ideologically" constructed selves which took the responsibility to guard its interests (in case of Islamization, these selves were the pro-Jihad factions whereas the Western Islamophobes should be considered the linguistically and ideologically constructed selves in the case of Islamophobia).

Moreover, the contemporary Pakistani Anglophone literature presents a site of subversion to both political narratives. In the case of Islamization, Muhammad Hanif's novel A Case of Exploding Mangoes provides a subversive stance on Zia's Islamization program. Instead of complying with the narrative of Islamization, it reveals the way political interests were served on the pretext of religion during the Cold war. On the other hand, Hanif Kureishi's The Black Album makes it problematic to suggest that it really subverted from the power-driven narrative of Islamophobia as most of its Muslim characters seem to fulfil the Western expectations. But when we come across Graham Huggan's (2001) assertion that most of the writers from marginal communities are notable for "stag[ing] marginality" in their works as an act of "parodying mainstream expectation of minority subjectivity" (pp. 83-104), we get to know that Kureishi too subverts from the political narrative of Islamophobia but in his own way, i.e., by making his Muslim characters parody mainstream expectations of Muslim subjectivity. Kureishi does provide a subversion to the political narrative of Islamophobia by highlighting the White racist behaviour towards Muslims. In Hugh Gardy's terms, he highlights the "fissures and cracks" in the Western civilized imagination that assumes itself to be harmonious, educated, and peace-loving-according to the Runneymede Trust's report. For example, it can be seen in the novel that Riaz and company's first armed venture was to defend a Bengali Muslim family from the recurring racial attacks.

In a nutshell, we conclude that both narratives, i.e., Islamization and Islamophobia, have a strong political stand: one aimed at containing the subversion which the power (Western capitalism) confronted in the form of communism and the other helped power to contain the subversion it confronted in the form of the rise of Muslim influence in the West. Nevertheless, looking at the overall body of the contemporary Pakistani Anglophone literature, and particularly Muhammad Hanif and Hanif Kureishi's selected novels with reference to Islamization and Islamophobia, we suggest that the Pakistani literature-unlike the political discourse - has been resisting the normative power structures and has always played a revelatory role. In the present case, it does not only "textualize and historicize" the eras in which the narratives of Islamization and Islamophobia met their heyday, but it also reveals the hidden politics behind them.

\section{Endnote:}

${ }^{1}$ In case of Islamization, power symbolizes the despotic regime of Gen. Zia in coalition with America and its capitalist allies. Whereas, in case of Islamophobia, it is only the West. 
Malik Haroon Afzal (Corresponding author)

University Sains Malaysia, Malaysia

ORCID Number: 0000-0001-8487-7165

Email: mharoon176@gmail.com

Mohamad Rashidi Mohd Pakri

University Sains Malaysia, Malaysia

ORCID Number: 0000-0003-2083-7775

Email: rashidi@usm.my

Nurul Farhana Low Abdullah

University Sains Malaysia, Malaysia

ORCID Number: 0000-0001-9670-5256

Email: nflow@usm.my

\section{References:}

Azam, Saleem. (1990). Shaheed-ul-Islam Muhammad Zia-ul-Haq. London: UK: Indus Thames Publishers.

Banerjee, Debjani. (2020). 'From cheap labor to overlooked citizens: Looking for British Muslim identities in Kamila Shamsie's Home Fire'. South Asian Review, DOI: 10.1080/02759527.2020.1835141

Brannigan, John. (1998). New historicism and cultural materialism. Hampshire: Macmillan Press Ltd.

Brook-Shepherd, Gordon. (1990). 'Gleaning from the international press'. In Azzam, S. (Ed). Shaheed-ul-Islam Muhammad Zia-ul-Haq, 145-146. London: Indus Thames Publishers.

Chaudry, Fariha. (2013). Hiding and seeking identity: The female figure in the novels of Pakistani Female writers in English: A feminist approach. Ph.D. Thesis [published], University of Huddersfield, UK.

Foucault, Michel. (1981). Power/knowledge: Selected interviews and other writings 1972-1977 (Ed. Colin Gordon; Colin Gordon et al, Trans.). London: Harvester Wheatsheaf.

Greenblatt, Stephen. (1980). Renaissance self-fashioning: From More to Shakespeare. Chicago and London: University of Chicago Press.

Greenblatt, Stephen. (1981). 'Invisible bullets: Renaissance authority and its subversion'. Glyph. Vol 8. 40-61.

Hanif, Muhammad. (2008). A case of exploding mangoes. London: Vintage.

Khan, Gohar Karim. (2013). Narrating Pakistan transnationally: Identity, politics and terrorism in Anglophone Pakistani Literature after " $9 / 11 " . \mathrm{PhD}$ Thesis.[published] University of Warwick, UK. 
Kureishi, Hanif. (1995). The black album. London: Faber \& Faber.

Langah, Nuqbah. (2019). Literary and non-literary responses towards 9/11 South Asia and beyond. India: Routledge.

Majed, Hasan. (2012). Islam and Muslim identities in four contemporary British novels. PhD thesis [published], University of Sunderland, UK.

Montrose, Louis A. (1997). 'Professing the renaissance: The poetics and politics of culture'. In Newton K.M. (Ed.). Twentieth-Century Literary Theory, 584591. Palgrave, London.

Morey, Peter. (2018). Islamophobia and the novel. NY: Columbia University Press.

Paracha, Nadeem F. (2018, November 18). 'Smokers corner: How Zia set the rule'. $D A W N$. Retrieved from https://www.dawn.com/news/1446325

Quin, Emelia. (2018). 'Deer crossing. moose crossing. old people crossing. children crossing: Reading Islamophobia through a vegan lens in Kamila Shamsie's Burnt Shadows'. The Journal of Commonwealth Literature. 53(1), 109-123.

Report, Runnymede Trust. (1997). Islamophobia: A challenge for us all. London: Runneymede Trust.

Riaz, Humaira. (2017). Racism and Islamophobia: A critique of selected American literary texts. PhD thesis. [unpublished], Fatima Jinnah Women University, Pakistan.

Saleem, Ali Usman. (2015). Paracolonialism: A case of post-1988 Anglophone Pakistani fiction. PhD Thesis, [published], University of Bedfordshire, UK.

Sharif, Mian Muhammad Nawaz. (1990). 'Zia as I know him'. In Azzam, S. (Ed). Shaheed-ul-Islam Muhammad Zia-ul-Haq, 39-45. London: Indus Thames Publishers.

Times, The. (1990). 'Gleaning from the international press'. In Azzam, S. (Ed). Shaheed-ul-Islam Muhammad Zia-ul-Haq, 140-141. London: Indus Thames Publishers. University Press.

Usmani, Taqi. (1990). 'Islamization of laws in Pakistan'. In Azzam, S. (Ed). Shaheed-ul-Islam Muhammad Zia-ul-Haq, 58-76. London: Indus Thames Publishers.

Zaidi, S. Akbar. (2017, November 1). 'Special report: Darkness descends 19771988'. DAWN. Retrieved from: https://www.dawn.com/news/1364410

Zunes, Stephen. (2017). 'Europe's refugee crisis, terrorism, and islamophobia'. Peace Review. 29 (1), 1-6. 